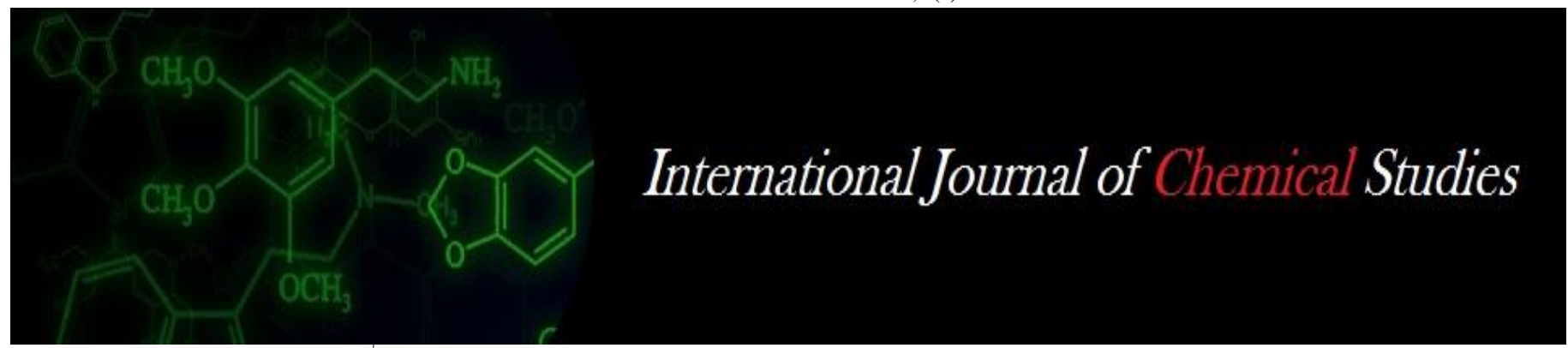

P-ISSN: 2349-8528

E-ISSN: 2321-4902

www.chemijournal.com

IJCS 2021; 9(1): 2985-2988

(C) 2021 IJCS

Received: 02-10-2020

Accepted: 08-11-2020

Saraswati Pandey

College of Agriculture, Indira

Gandhi Krishi Vishwavidyalaya,

Raipur, Chhattisgarh, India

PC Chaurasiya

College of Agriculture, Indira Gandhi Krishi Vishwavidyalaya,

Raipur, Chhattisgarh, India

Rajshree Gayen

College of Agriculture, Indira

Gandhi Krishi Vishwavidyalaya,

Raipur, Chhattisgarh, India
Corresponding Author: Saraswati Pandey

College of Agriculture, Indira

Gandhi Krishi Vishwavidyalaya,

Raipur, Chhattisgarh, India

\section{Effect of genotypes and planting dates of broccoli on growth, stalk length and yield attributes}

\author{
Saraswati Pandey, PC Chaurasiya and Rajshree Gayen
}

DOI: https://doi.org/10.22271/chemi.2021.v9.i1ap.11681

\begin{abstract}
Broccoli (Brassica oleracea var. Italica Plenck) is a cole crop under Brassicaceae family and is originated from eastern Mediterranean region. Field experiment was conducted during Rabi season of 2017-18 at the Potato \& Temperate Fruit Research Station, Mainpat, Surguja on planting dates and genotypes of broccoli. The experiment was replicated thrice in split plot design during 2017-18. It comprised 6 dates of transplanting i.e. $1^{\text {st }}$ October, $16^{\text {th }}$ October, $1^{\text {st }}$ November, $16^{\text {th }}$ November, $1^{\text {st }}$ December and $16^{\text {th }}$ December in main plot. There were 4 sub plot treatment i.e. genotypes (Palam Haritika, Palam Samridhi, KTS-1 and Aishwarya). Present investigation revealed that transplanting on $16^{\text {th }}$ of October and genotype Palam Samridhi recorded superior result as compared to other transplanting dates and varieties. Maximum results were found in plant height $(54 \mathrm{~cm})$, stalk length $(13 \mathrm{~cm})$ and head yield (14.438 ton/ha) on $16^{\text {th }}$ of October whereas Genotype Palam Samridhi gives maximum plant height $(55.33 \mathrm{~cm})$, Stalk length $(13.5 \mathrm{~cm})$ and head yield $(14.918 \mathrm{ton} / \mathrm{ha})$. Interaction effect of date of transplanting and genotype was found non significant but numerically the interaction effect of $\mathrm{D}_{2} \mathrm{~V}_{2}(16$ th of October and genotype Palam Samridhi) was best among the all treatment combination.
\end{abstract}

Keywords: Broccoli, genotype, date of transplanting, stalk length, head yield

\section{Introduction}

Broccoli (Brassica oleracea var. Italica Plenck) is a cole crop under Brassicaceae family with chromosome number 18. It is originated from eastern Mediterranean region and was imported into Italy. It is one of the exotic vegetables that India has added. The word "Brassica" means to cut the head off. Broccoli is an Italian word derived from brachium, meaning arm or branch in Latin. Broccoli soup is a delicacy in hotels and restaurants that are healthier than other corks, such as cabbage, cauliflower. It is used for curries, soups and pickles and is also eaten as a salad and cooked with potato as a single or mixed vegetable (Thamburaj and Singh, 2001) ${ }^{[7]}$. $25,310,691$ tonnes of cauliflower and broccoli are produced each year worldwide. (FAO figures, 2019). China is the world's largest producer of cauliflower and broccoli i.e. 10,263,746 tonnes per year whereas India comes in second position of annual production $(8,199,000$ tonnes). Together, China and India produce more than $70 \%$ of the world's total. Cruciferous crop yields are also adversely affected by temperature variations. Therefore, planting dates have a big influence on the marketable yield. Technology should be standardized on different aspects of production, particularly varietal selection, optimum planting date and doses of broccoli fertilizers for higher and more economical yields.

As this crop gaining the importance due to its high nutritive value and anticancer properties, it is very necessary to cope up with demand to increase the production of broccoli and this can be achieved by using proper date of planting and find out the suitable variety for this region.

\section{Material and Methods}

The field was conducted at Northern Hill Zone (Mainpat) of Chhattisgarh during Rabi season of the year 2017-2018. Geographically, Mainpat is situated at northern hill zone of Chhattisgarh in surguja district and is between $22^{\circ} 50^{\prime} 13.2^{\prime \prime} \mathrm{N}$ Latitude and $83^{\circ} 18^{\prime} 54^{\prime \prime} \mathrm{E}$ Longitude at a height of 1085 meters above the mean sea level. The maximum rainfall recorded during the test was $94.40 \mathrm{~mm}$ in first week of October. The maximum temperature during crop period varied from $23.20{ }^{\circ} \mathrm{C}$ in the last week of January to $31.37{ }^{\circ} \mathrm{C}$ in the first week of November. Plant growth and development depends on soil aeration and production. 
The soil of the experimental field was Inceptisols "known as "Sandy clay loam". The soil was neutral in the middle with a low $\mathrm{N}$, medium $\mathrm{P}$ and $\mathrm{K}$ ratio. This test was placed on the split plot design and the treatment methods were replicated thrice. The treatments comprised of total twenty four treatments consisting of six main plots based on dates of transplanting and four sub- plot which are varieties of broccoli.

For the record of pre harvest and post-harvest observation, five plants were selected randomly from each plot. The details of pre and post-harvest observations recorded are height of plant, leaves per plant, leaf length, stalk length head yield per plot $(\mathrm{kg})$, head yield per hectare and days to last harvest. For the statistical analysis of data a method of analysis of variance was used and Split plot Design was used to test the significance of means between treatments.

\section{Results and Discussion}

\section{Effect of varieties and transplanting dates on height of} plant

Plant height was recorded 40, 60 days after transplanting and at the time of harvest. It was revealed in the study that there were random changes in plant height as they were recorded on different dates for transplantation and genotype.

In the data analysis it is evident that the date of transplantation showed a significant difference in plant height. From the table it was found that the plant was transplanted on the 1st of October and the 16th of December obtained a maximum height of $37 \mathrm{~cm}, 46 \mathrm{~cm}$ and $54 \mathrm{~cm}$ at 40 DAT, 60 DAT and at harvest time respectively. It has also been noted in detail that there has been a significant decline in crop height where transplanting has been delayed until $1^{\text {st }}$ October. There was a significant effect on the growth of broccoli at $5 \%$ level of significance when date for transplantation changed. The scientist has previously concluded that there will be significant effect in plant height of broccoli when different date of transplanting was done. Singh (2001) [7] reported maximum plant height of $41.75 \mathrm{~cm}$ in broccoli when transplanted in October as compared to December.

Table 1: Mean plant height $(\mathrm{cm})$ as influenced by date of transplanting and genotype

\begin{tabular}{|c|c|c|c|}
\hline \multirow{2}{*}{ Treatment } & \multicolumn{3}{|c|}{ Plant Height } \\
\cline { 2 - 4 } & 40 DAT & 60 DAT & At Harvest \\
\hline \multicolumn{4}{|c|}{ Date of Transplanting (D) } \\
\hline D1 & $37.00^{*}$ & 45.75 & $54.00^{*}$ \\
\hline D2 & 36.00 & 42.00 & 48.50 \\
\hline D3 & 35.50 & 41.50 & 46.75 \\
\hline D4 & 35.25 & 40.50 & 46.65 \\
\hline D5 & 33.50 & 40.25 & 45.50 \\
\hline D6 & 37.00 & 46.00 & 54.00 \\
\hline S.Em \pm & 0.972 & 1.18 & 1.364 \\
\hline CD at 5\% & N/A & 3.765 & 4.352 \\
\hline \multicolumn{4}{|c|}{ Genotype (V) } \\
\hline V1 & 30.83 & 39.33 & 46.00 \\
\hline V2 & 37.33 & 44.33 & 48.10 \\
\hline V3 & 35.00 & 39.83 & 47.50 \\
\hline V4 & $39.67 *$ & $47.16^{*}$ & $55.33^{*}$ \\
\hline S.Em \pm & 0.494 & 0.588 & 0.671 \\
\hline CD at 5\% & 1.422 & 1.692 & 1.931 \\
\hline
\end{tabular}

It was also revealed from the data that the growth in relation to plant height varies according to the Genotype. Genotype V4 (Aishwarya) recorded maximum plant height, $39.67 \mathrm{~cm}$, $47.16 \mathrm{~cm}$, and $55.33 \mathrm{~cm}$ at 40 DAT, 60 DAT and at harvest time respectively. A small plant height of $30.83 \mathrm{~cm}, 39.33 \mathrm{~cm}$ and $46 \mathrm{~cm}$ in 40 DAT, 60 DAT and at harvest time was found in genotype V1 (Palam haritika). The results showed that there was a significant difference in plant height at a significance level of 5\% when a different variety of broccoli was transplanted. The variation in plant height among varieties might be due to inherent genotypic characteristics or for the variations on agro-climate condition (Tejaswani et al., 2018) ${ }^{[8]}$. These finding are in agreement with those reported by Thapa et al., 2012 ${ }^{[9]}$ and Giri et al. (2013) ${ }^{[5]}$ in broccoli.

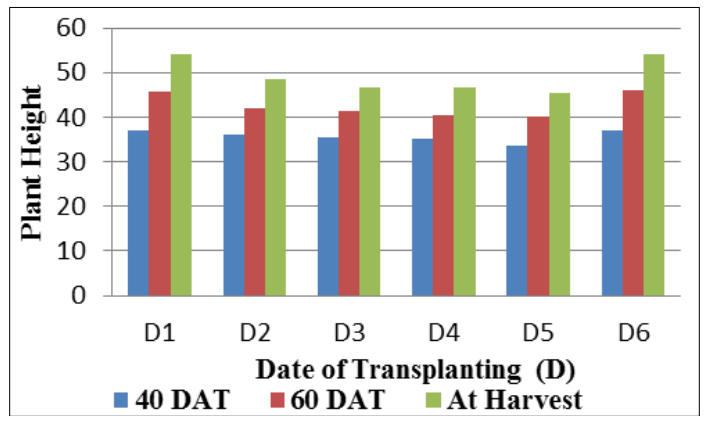

Fig 1: Mean plant height $(\mathrm{cm})$ as influenced by date of transplanting

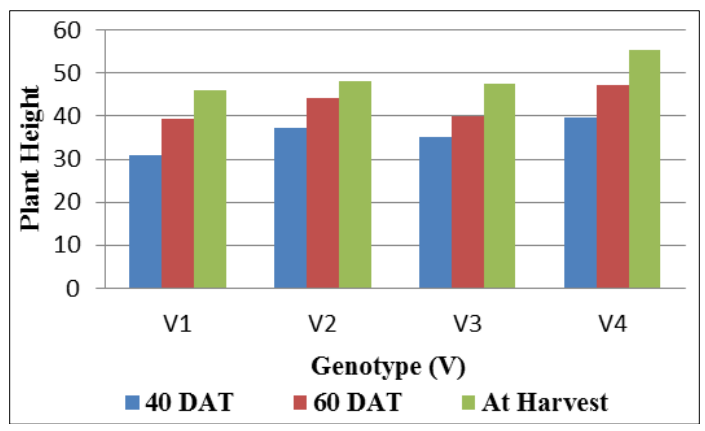

Fig 2: Mean plant height $(\mathrm{cm})$ as influenced by genotype

\section{Effect of varieties and transplanting dates on stalk length of broccoli}

Stalk length were recorded 40, 60 days after transplanting and at harvest time. Details regarding stalk length as influenced by various transplant dates and genotype are presented in Table 2 and shown in figs. 3 and fig. 4 respectively. From the data analysis it is evident that the date of transplantation showed a significant difference in stalk length and was found that the plant was transplanted on the 1st of October obtained a maximum stalk length i.e. $10.25 \mathrm{~cm}, 11 \mathrm{~cm}$ and $13 \mathrm{~cm}$ at 40 DAT, 60 DAT and at harvest time respectively. Minimum stalk length was recorded $9.5 \mathrm{~cm}, 10.5 \mathrm{~cm}$ and $11.25 \mathrm{~cm}$ at 40 DAT, 60 DAT and at harvest time respectively on $16^{\text {th }}$ of October. Result showed that there was a significant difference in the stalk length on different dates of transplantation at $5 \%$ level of significance.

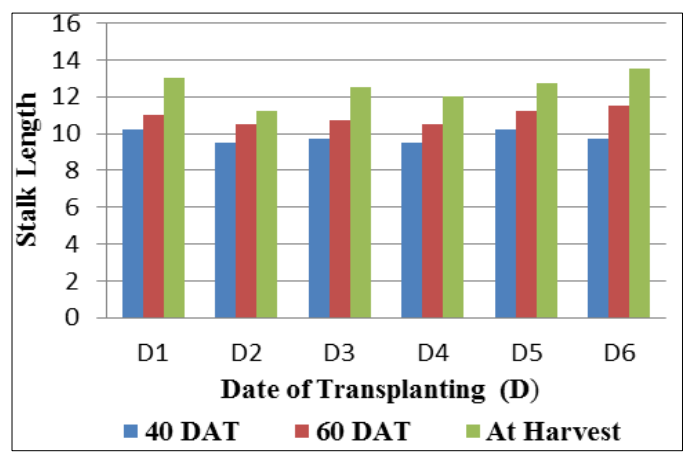

Fig 3: Stalk Length $(\mathrm{cm})$ as influenced by date of transplanting 


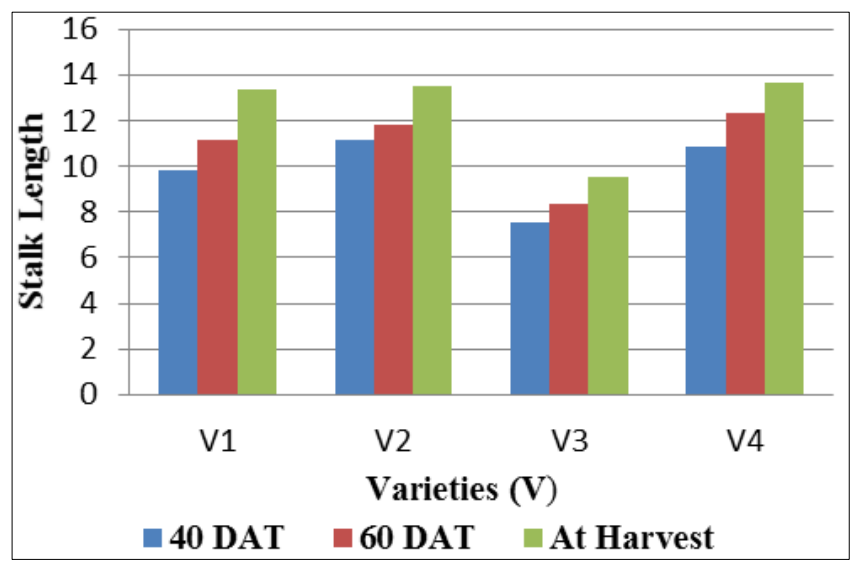

Fig 4: Stalk Length (cm) as influenced by genotype

It was also revealed from the data that the growth in relation to stalk length varies according to the Genotype. Genotype $\mathrm{V}_{2}$ (Palam samridhi) recorded maximum stalk length i.e. 11.17 $\mathrm{cm}, 11.83 \mathrm{~cm}$ and $13.5 \mathrm{~cm}$ at 40 DAT, 60 DAT and at harvest time respectively. A small stalk length of $7.5 \mathrm{~cm}, 8.33 \mathrm{~cm}$ and $9.5 \mathrm{~cm}$ at 40 DAT, 60 DAT and at harvest time was found in genotype $\mathrm{V}_{3}$ (KTS-1). The results showed that there was a significant difference in stalk length at a significance level of $5 \%$ when a different variety of broccoli was transplanted.

Table 2: Mean table of Stalk Length $(\mathrm{cm})$ as influenced by date of transplanting and genotype

\begin{tabular}{|c|c|c|c|}
\hline \multirow{2}{*}{ Treatment } & \multicolumn{3}{|c|}{ Stalk Length } \\
\cline { 2 - 4 } & 40 DAT & 60 DAT & At Harvest \\
\hline \multicolumn{4}{|c|}{ Date of Transplanting (D) } \\
\hline D1 & $10.25^{*}$ & $11.00^{*}$ & $13.00^{*}$ \\
\hline D2 & 9.50 & 10.50 & 11.25 \\
\hline D3 & 9.75 & 10.75 & 12.50 \\
\hline D4 & 9.50 & 10.50 & 12.00 \\
\hline D5 & 10.25 & 11.25 & 12.75 \\
\hline D6 & 9.75 & 11.50 & 13.50 \\
\hline S.Em \pm & 0.283 & 0.319 & 0.363 \\
\hline CD at 5\% & N/A & N/A & 1.159 \\
\hline \multicolumn{4}{|c|}{ Genotype (V) } \\
\hline V1 & 9.83 & 11.16 & 13.33 \\
\hline V2 & $11.17 *$ & $11.83 *$ & $13.50^{*}$ \\
\hline V3 & 7.50 & 8.33 & 9.50 \\
\hline V4 & 10.83 & 12.33 & 13.66 \\
\hline S.Em \pm & 0.138 & 0.150 & 0.173 \\
\hline CD at 5\% & 0.398 & 0.433 & 0.499 \\
\hline
\end{tabular}

Effect of varieties and transplanting dates on head yield of broccoli

Head yield was recorded at different date of transplanting and genotype and are presented in Table 3 and are shown in figs. 5 and fig. 6 respectively. It was revealed in the study that there was difference in head yield as they were recorded on different dates for transplantation and genotype.

In the data analysis it is evident that the date of transplantation showed a significant difference in head yield. From the table it was found that the plant was transplanted on the $16^{\text {th }}$ of October showed maximum gross head yield. It has also been noted in detail that there has been a significant decrease in head yield where transplanting has been delayed until $1^{\text {st }}$ October. The minimum head yield was found as 11.245 ton/ ha on $16^{\text {th }}$ of December. Khaton et al. (2012) ${ }^{[6]}$ reported different transplanting dates showed significant influence on the yield and yield contributing characters of broccoli. The decrease in yield with the delay in sowing was also reported by Yoldas and Esiyok (2004) ${ }^{[15]}$ and Wlazo and Kunicki (2003) ${ }^{[14]}$.

It was also revealed from the data that head yield varies according to the Genotype. Genotype $\mathrm{V}_{2}$ (Palam Samridhi) recorded maximum head yield 14.918 tonnes whereas minimum head yield was found to be 10.535 tonnes to the genotype Aishwarya. Variety which is superior in its vegetative growth and leaf area allows plant to receive more light energy and consequently more photosynthesis and photosynthetic metabolism which translocate and stored in main yield (Thakur et al., 2016b) ${ }^{[11]}$. These finding are supported with those of Thapa and Rai (2012) [9], Thapa et al. (2013) ${ }^{[10]}$ and Tejaswini et al. (2018) ${ }^{[8]}$ in broccoli.

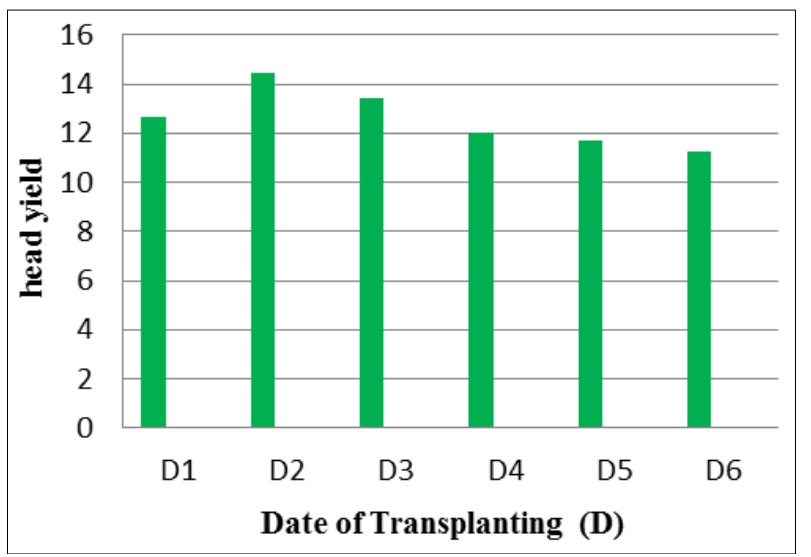

Fig 5: Head yield (ton/ha) as influenced by date of transplanting

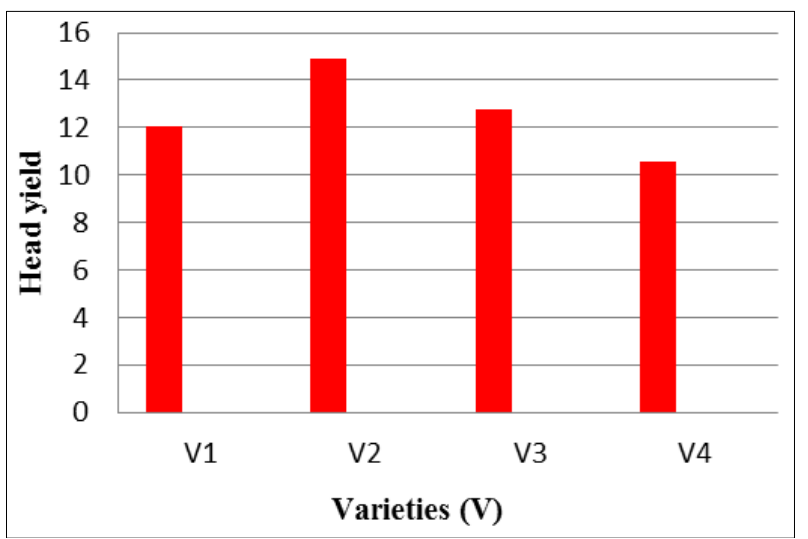

Fig 6: Gross head yield (ton/ha) as influenced by genotype

Table 3: Mean table of head yield (ton/ha) as influenced by date of transplanting and genotype

\begin{tabular}{|c|c|}
\hline Treatment & Head Yield \\
\hline \multicolumn{2}{|c|}{ Date of Transplanting (D) } \\
\hline D1 & 12.638 \\
\hline D2 & $14.438^{*}$ \\
\hline D3 & 13.408 \\
\hline D4 & 12.025 \\
\hline D5 & 11.705 \\
\hline D6 & 11.245 \\
\hline S.Em \pm & 0.33 \\
\hline CD at 5\% & 1.055 \\
\hline \multicolumn{2}{|c|}{ Genotype } \\
\hline V1 & 12.073 \\
\hline V2 & $14.918^{*}$ \\
\hline V3 & 12.778 \\
\hline V4 & 10.535 \\
\hline S.Em \pm & 0.178 \\
\hline CD at 5\% & 0.512 \\
\hline
\end{tabular}




\section{References}

1. Ahmed MJ, Siddique W. Effect of sowing dates on growth and yield of broccoli (Brassica oleracea L.) under Rawalakot condition. Asian Journal Plant Science 2004;3:167-69.

2. Anonymous. National Horticulture Board 2014. http:www.nhb.gov.in.

3. Bose TK, Som MG, Kabir J. Vegetable Crops. NayaProkash, Calcutta (India) 1986, 177.

4. Dhar S, Singh D. Performance of cauliflower genotypes for yield and resistance against black rot (Xanthomonascampestris var. campestris). Indian Journal Horticulture 2014;71(2):197-201.

5. Giri RK, Sharma MD, Shakya SM, GC YD, Kandel TP. Growth and yield responses of broccoli cultivars to different rates of nitrogen in Western chitwan, Nepal. Agriculture Science 2013;4(7A):8-12.

6. Khatun K, Hossain F, Saha SR. Effect of different transplanting dates on the growth and yield of broccoli. Journal of Exp Bio Science 2012;3:13-18.

7. Singh AK. Head yield of broccoli as influenced by different dates of transplanting under low-hills subtropical condition of Himachal Pradesh. Hort J 2001;14:66-67.

8. Tejaswini T, Varma LR, Vema P, Prajapathi RI, Vani FB. Performance of different varieties with respect to growth, yield and quality of broccoli (Brassica oleracea var. italica L.) under North Gujarat conditions. International Journal Curr. Microbiology App Sci 2018;(76):690-698.

9. Thapa U, Rai R. Evaluation of sprouting broccoli (Brassica oleracea var. italica) genotypes for growth, yield and quality. International Journal Agriculture Science 2012;4(7):284-286.

10. Thapa U, Rai R, Lyngdoh YA, Chattopadhyay SB, Prasad PH. Assessment of producing quality sprouting broccoli (Brassica oleracea var. italica) under cover and open condition. African Journal of Agriculture Research 2013;8(15):1315-1318.

11. Thakur R, Kustwah SS, Shama RK, Singh OP. Growth and yield of sprouting broccoli (Brassica oleracea var. italica) varieties under open field and naturally ventilated polyhouse condition. The Bioscan 2016b;(114):23232326.

12. Thakur S, Thakur R, Mahta DK. Evaluation of different genotypes of broccoli in dry temperate conditions of Kinnaur district of Himachal Pradesh in India Int. Journal Science and Technology 2016c;(53):1613-1679.

13. Thamburaj S, Pillai OAA, Anbu S, Shanmugardu KG. Preliminary studies on the performance of certain varieties of cauliflower (Brassica oleracca var. botrytis) at Coimbature. South Indian Hort 1980;28(3):82-84.

14. Wlazo A, Kunicki E. The effect of transplant age and planting time on yield and quality of autumn broccoli Folia Horticulture 2003;15:33-40.

15. Yoldas F, Esiyok D. Effects of plant spacing, sowing and planting date on yield and some quality parameters of broccoli. Ege Universities Ziraat Facultesi Dirges 2004;41(2):37-48. 